\title{
Research on the Relationship between Trainers' Turnover Intention and Organizational Justice
}

\author{
Ersan Tolukan ${ }^{1} \&$ Yakup Akyel $^{2}$ \\ ${ }^{1}$ Department of Sport Sciences, Faculty of Health Sciences, Ankara Yıldırım Beyazıt University, Ankara, Turkey \\ ${ }^{2}$ Department of Elementary Education, Faculty of Education, Ahi Evran University, Kırşehir, Turkey \\ Correspondence: Ersan Tolukan, Department of Sport Sciences, Faculty of Health Sciences, Ankara Yildırım Beyazit \\ University, Ankara, 06010, Turkey. E-mail: ersantolukan@gmail.com
}

Received: January 30, 2019

Accepted: February 24, 2019

Online Published: February 25, 2019

doi:10.5430/ijhe.v8n1p181

URL: https://doi.org/10.5430/ijhe.v8n1p181

\begin{abstract}
The aim of this study was to investigate the relationship between the organizational justice levels and the turnover intention of trainers working in different departments. The present research was designed with relational screening model. Organizational Justice Scale developed by Kim (2009) and adapted to Turkish by Sayın and Şahin (2017) and the Turnover Intention Scale developed by Mobley et al. (1978) were applied to 382 volunteer participants. One-way analysis of variance was used in order to determine whether there was a significant difference in turnover intention and organizational justice levels according to demographic characteristics of participants. Pearson correlation coefficient was calculated in order to determine the level of relationship between the participants' organizational justice levels and their turnover intention. Significance level was taken as 0.05. At the end of the study, it was determined that there was a negative and medium level relationship between the organizational justice levels of the trainers and their turnover intention. When evaluating them in terms of demographic variables, it was determined that as the level of educational level of the trainers increases, the level of distribution justice sub-dimension decreases and the levels of organizational perception of the trainers, whose branches are the combat sport, were low.
\end{abstract}

Keywords: organizational justice, intention to leave, trainer

\section{Introduction}

In today's life, individuals want to continue their activities in an environment where justice is established. Various problems emerge in the environments where justice cannot be established. At the same time, the negative perception of organizational justice is said to cause many unwanted employee behavior by the organization (Greenberg, 2002; Masterson, Lewis, Goldman and Taylor, 2000). One of the most important of these negative behaviors is that the members of the organization want to leave the organization they are in. However, in the literature review, the concept of turnover, which is associated with organizational justice, has not been the behavior to resign, but the turnover intention (Colquitt, 2001; Chang and Dubinsky, 2005).

Organizational justice is a concept used to reveal the effect of justice in organizations. It can be defined as the positive perception of the employees on the decisions and practices of the managers about the organization and employees. In other words, organizational justice can be defined as perceptions of the employees on how the wages, rewards, penalties and promotions are done within the organization, how these decisions are taken or how these decisions are told to the employees (İçerli, 2010). Greenberg (1990) stated that organizational justice is necessary for the personal satisfaction of the employees and the functional effectiveness of the organizations. Organizational justice is about how employees perceive and react to justice in their work-related activities (Ployhart and Ryan, 1997). Individuals' perceptions of organizational justice are focused on assessing the decisions and behaviors of how much justice will be provided in terms of distributing the costs and benefits arising from organizational activities among individuals and groups (Demir, 2007).

Organizational justice includes the perceived justice of all the mutual changes occurring socially or economically within the organization and the relations of the individuals with their superiors, colleagues and the organization as a social system (Y1lmaz, 2004). In short, those works in a justice organization concern the behavior of managers as fair, moral and rational (Eğilmezkol, 2011). These situations can affect their attitudes and behaviors well or badly and have a positive or negative effect on employee performance and the success of the organization (Ar1, 2015). 
Employees who think that they work in an unfair organization decrease their loyalty to their institutions and as a result they leave their jobs. Therefore, managers need to know the importance of organizational justice and the attitudes and behaviors of employees in case of injustice. It is because justice brings individuals closer to the organization and employees, injustice keeps the individuals away from each other and organization (Söyük, 2007). These negative attitudes and behaviors of the employees against the organization can only be changed by abandoning the unfair system in the organization (Çağ, 2011).

The basis of the organizational justice perception is that both the organization and the employees have to be obliged and both sides accept their responsibilities. In addition, trust in management, their evaluations about their managers, the harmony in the work environment and the job satisfaction have an impact on organizational justice perceptions of employees. As a result, employees, according to these factors, have a judgment about justice in the organization they are a member of (Kiray, 2011).

Organizational Justice is divided into three sub-dimensions, namely, justice of distribution, procedural justice, and interaction justice, which some researchers include in the dimension of procedural justice, while some researchers consider it a separate dimension (Luo, 2007). In this context, employees have a fair understanding of the distribution of resources in the organization, namely the perception of "distributional justice"; the perception of "procedural justice" in respect of the methods and processes in the decisions taken about these, and finally the perception of "interaction justice" regarding the interactions between individuals during the implementation of this procedure.

Turnover is the employee's abandonment of the existing workplace by his/her own decision or by the will of the organization. Employee leaving the job is one of the results that emerge when dissatisfaction occurs (Eren, 2007).

Many factors that arise in business life affect the employees' turnover intention. Apart from the institution's wage and promotion policy, the management's attitude, the general economic situation of the country and the social factors, the factors such as expectation of finding a better job, age, gender, education, performance, stress and co-operation affect the turnover intention (Y1lmaz and Halıc1, 2010). Weisberg and Kirschenbaum (1991) also stated that turnover intention decreases as the age and experience increase, and turnover intention increases as the level of education and vocational level increases. Therefore, the factors affecting the turnover intention in general terms can be examined as economic, in-house, personal living conditions, work tiredness and depression (Agin, 2010).

With the employee leaving from the organization, the cost burden occurs in the organization. These costs are divided into several ways. Processes such as the availability of a new employee, recruitment of new employee and training of the employee include direct costs. Decrease in the motivation of the employees who continue to work in the organization without leaving the organization, increase in the workloads of the others and loss of social capital include indirect costs for the organization (Yildiz, 2013). When these negative effects and costs are considered, an employee's turnover has negative effects both on the loss of a qualified manpower and on the recruitment, training and adaptation of a new employee (Bannister and Griffeth, 1986). Miller (2007) stated that high turnover rates damage the organizations due to the financial costs such as re-recruitment, orientation, and turnover, as well as reduction in profitability and deterioration in productivity.

Employees spend most of their daily lives in their organizations. Employees' feelings for the organization have organizational as well as individual consequences. Employees have negative behaviors when they think that the organization they work for is not fair (İyigün, 2012; Tingül, 2018). It is an inevitable result that employees exhibit such negative attitudes and behaviors due to their perception of injustice. These negative emotions and behaviors will result in the intention of the employees to leave the job and even result in turnover when they find another alternative job (Kusci, 2014; Tingül, 2018). Employees show an open tendency to resign when they think that they are not treated fairly (Gürpınar, 2006). The positive qualities of the business environment or the positive attitudes of employees for their work do not prevent this trend from being exhibited. Justice in an organization is an indication that the organization is committed to its employees. This situation will have positive effects on employees' commitment to the organization (Fischer, 2004).

The studies on the individual outputs of employees' perceptions of organizational justice and turnover intention are frequently encountered in the literature (Vigoda, 2000; Cohen-Charash and Spector, 2001; Lipponnen et al., 2004; Byrne 2005; Gürpınar, 2006; Özer and Günlük, 2010; Örücü and Özafşarlığlu, 2013; Tingül, 2018; Sanı and Yavuz, 2018).

Thereby, if the coaches are considered as the director who educate his athletes and team in line with the specific purposes and focus on success (Akbulut and Altınkök, 2018), sports clubs and sports enterprises evaluated in the service sector and trainers working for the public sports institutions are the most important factor for the institution 
in which they work as in all service sectors. Organizational justice and turnover intentions of employees in these organizations are seen as important in terms of the performance of the organization and there is a great responsibility for the managers not to create negative problems within the organization. This situation can be better understood by the managers of the organization, and can help them to be more effective and efficient in the direction of the organization's performance.

\section{Method}

\subsection{Research Model}

In this study, it was aimed to determine the relationship between the trainers' organizational justice levels and their turnover intention. At the same time, it is aimed to find out whether there is a significant difference between the organizational justice levels and turnover intention according to the demographic characteristics of the trainers. The research conducted in the context of this aim is designed with a relational survey model. With relational survey, it is aimed to determine the existence and degree of interchange between multiple variables (Karasar, 2009).

\subsection{Population and Sample}

According to the statistical reports of the General Directorate of Sport, the study population consists of 15197 trainers working in the fields of team sports, individual sports, combat sports, dance games and folklore. Considering that the number of samples that can represent the trainers determined for the study population is between $95 \%$ confidence interval and has 0.05 error amount. 382 trainers selected by the convenience sampling method constitute the sample of the research. The convenience sampling is a sample which is applied to persons who are in the immediate vicinity and easy to reach if there is no aforesaid region, who are available and volunteers to participate in the research (Erkuş, 2013).

\subsection{Data Collection Tools}

There are 8 items including personal information of the trainers in the data collection tools. In addition to the personal information form, the 17-item "Scale of Organizational Justice" and the 3-item "Turnover intention Scale" were used.

\subsubsection{Organizational Justice Scale}

In order to determine the level of organizational justice of trainers, the Organizational Justice Scale, which was adapted to Turkish by Sayın and Şahin (2017) and developed by Kim (2009), was used. Within the scope of the scale, there are 17 items in three dimensions, namely distribution justice, procedural justice and interactional justice. The items were graded in 5-point Likert-type and high scores from the scale indicated that organizational justice was high.

Model-data fit indices indicated that model-data fit of the scale adapted to the Turkish was provided with three dimensions and 17 items $(\mathrm{X} 2 / \mathrm{sd}=3.93$; RMSEA=0.086; $\mathrm{CFI}=0.97$; $\mathrm{IFI}=0.97$; NFI $=0.96)$. After the confirmatory factor analysis, the calculated item-total correlation coefficients of the scale items were found to vary between 0.605 and 0.846 . In order to determine the reliability of the responses to the scale items, the Cronbach alpha coefficient was calculated and the coefficients varied between 0.918 and 0.957 (Sayın and Şahin, 2017).

\subsubsection{Turnover Intention Scale}

To measure the level of self-evaluation intentions of employees to continue to work or to resign, the 3-item Turnover Intention Scale, which was developed by Mobley, Horner and Hollingsworth (1978), was used. The answers were taken with a 5-point Likert scale ( $1=$ Strongly disagree, $5=$ Strongly agree). Cronbach's alpha was found to be 0.904 as a result of the examination of the reliability after the factor analysis was performed.

Varimax factor rotation option was used in the analysis of the main components applied to the data by Örücü and Özafşarlıoğlu (2013). It explains $83.908 \%$ of the total variance under a factor of 3 variables. The reliability analysis was performed to test the reliability of the Turnover Intention Scale (Cronbach Alfa). As a result of the reliability analysis of the scale, the reliability value of the data was determined as 0.904 . This result shows that the Turnover Intention scale has a high degree of reliability.

\subsection{Data Analysis}

The data collected through the scale applied to the participants were recorded in the SPSS-21 package program. When the distribution of data was examined, it was found that no data showed any extreme value. It was observed that the skewness and kurtosis values of the score distributions of the data collected from the organizational justice scale and the turnover intention scale, which were applied to 382 trainer varied between -1 and 1 . It is seen that the 
distribution is normal when the skewness values are examined before examining the relationship between the scales and the difference between the scores of participants from the scales applied according to the demographic characteristics. It is stated that skewness and kurtosis coefficients can be accepted to be between -1 and 1 as a measure of normality assumption (Morgan, Leech, Gloeckner and Barrett, 2004). When examining the homogeneity of the test variances, namely the distribution of the Levene homogeneity test, it was concluded that the test variance of the score distribution according to Levene statistic p>, 05 realized homogeneously, namely the homogeneity assumption was achieved. It is seen that the distribution of the score obtained from the scales is continuous data and at the level of the scale with equal intervals. The fact that two samples (groups) are independent of each other, the dependent variables are measured at the scale or ratio scale level and the assumptions of normality and homogeneity have been achieved meet the parametric test assumptions (Köklü, Büyüköztürk and Bökeoğlu, 2007). The skewness and kurtosis values of the measurements are shown in Table 1.

Table 1. Skewness and Kurtosis Values regarding the Score Distributions of Trainers from Scales

\begin{tabular}{lll}
\hline $\mathrm{N}=382$ & Skewness & Kurtosis \\
\hline Distribution Justice &,- 211 &,- 723 \\
Procedural Justice &,- 443 &,- 258 \\
Interactional Justice &,- 498 &, 028 \\
Organizational Justice Scale &,- 332 &,- 169 \\
Turnover Intention Scale &, 330 &,- 418 \\
\hline
\end{tabular}

The relationship between the trainers' organizational justice levels and turnover intentions was examined through Pearson correlation analysis. Independent-Samples T-Test analysis was used to examine whether there was a significant difference between the scores of the trainers obtained from the scales according to their gender and marital status (Can, 2014). One-Way ANOVA analysis was used to examine whether there was a significant difference between the scores of the trainers obtained from the scales according to their age, educational status, the training category, the branches, the level of coaching certificate. Tukey test from multiple comparison (Post Hoc) tests was selected for the comparison of groups in case of there was a significant difference in the context of variables which were more than two groups in one-way variance analysis.

\section{Results}

3.1 First Sub-Problem: Is There a Relationship between the Organizational Justice Levels of Trainers and Their Turnover Intentions?

Table 2. Pearson Correlation Analysis Results regarding the Relationship between Trainers' Organizational Justice Levels and Turnover Intention

\begin{tabular}{|c|c|c|c|c|c|}
\hline & & $\begin{array}{l}\text { Distribution } \\
\text { Justice }\end{array}$ & $\begin{array}{l}\text { Procedural } \\
\text { Justice }\end{array}$ & Interactional Justice & $\begin{array}{c}\text { Organizational } \\
\text { Justice Scale }\end{array}$ \\
\hline \multirow{3}{*}{ Turnover Intention Scale } & $\mathrm{r}$ &,$- 31(* *)$ &,$- 34(* *)$ &,$- 35(* *)$ &,$- 38(* *)$ \\
\hline & $\mathrm{p}$ &, 000 & ,000 & ,000 & ,000 \\
\hline & $\mathrm{N}$ & 382 & 382 & 382 & 382 \\
\hline
\end{tabular}

$* \mathrm{p}<.05$

In Table 2, the relationship between the organizational justice levels of trainers and their turnover intentions is examined. It is seen that there is a low level negatively significant relationship between the justice levels of "distribution justice" sub-dimension of organizational justice scale and the trainers' turnover intentions according to $\mathrm{r}=-.31, \mathrm{p}=.000<.05$. There is a negatively significant relationship between the justice levels of "procedural justice" sub-dimension of organizational justice scale and the trainers' turnover intentions according to $r=-.34, p=.000<.05$ at a slightly more than the low level. There is a negatively significant relationship between the justice levels of "interactional justice" sub-dimension of organizational justice scale and trainers' turnover intentions according to $\mathrm{r}=-.35, \mathrm{p}=.000<.05$ between low level and medium level. There is a negatively significant relationship between the organizational justice levels and the turnover intentions of the trainers according to $r=-.38, p=.000<.05$. As the level of organizational justice of the trainers decreases, their turnover intentions increase. 
3.2 Second Sub-Problem: Is there a Significant Difference between the Levels of Organizational Justice and between the Turnover Intentions of the Trainers According to the Educational Status?

Table 3. One-Way ANOVA Results regarding the Significant Differences between the Organizational Justice Levels of the Trainers and between Their Turnover Intentions according to their Educational Status

\begin{tabular}{|c|c|c|c|c|c|c|c|}
\hline & Educational Status & $\mathrm{N}$ & $\overline{\mathrm{X}}$ & S & $F(2-379)$ & $\mathrm{p}$ & $\begin{array}{l}\text { Post Hoc } \\
\text { (Tukey) }\end{array}$ \\
\hline \multirow{3}{*}{ Distribution Justice } & High School & 110 & 12,95 & 4,50 & \multirow{3}{*}{3,43} & \multirow{3}{*}{,033* } & \multirow{3}{*}{$1>3,2>3$} \\
\hline & Bachelor's degree & 240 & 12,70 & 4,19 & & & \\
\hline & Master's degree & 32 & 10,75 & 4,06 & & & \\
\hline \multirow{3}{*}{ Procedural Justice } & High School & 110 & 23,54 & 6,68 & \multirow{3}{*}{, 86} & \multirow{3}{*}{, 423} & \\
\hline & Bachelor's degree & 240 & 23,30 & 6,67 & & & \\
\hline & Master's degree & 32 & 21,81 & 5,93 & & & \\
\hline \multirow{3}{*}{ Interactional Justice } & High School & 110 & 21,58 & 5,02 & \multirow{3}{*}{1,47} & \multirow{3}{*}{, 230} & \\
\hline & Bachelor's degree & 240 & 20,90 & 5,62 & & & \\
\hline & Master's degree & 32 & 19,75 & 6,38 & & & \\
\hline \multirow{3}{*}{$\begin{array}{l}\text { Organizational Justice } \\
\text { Scale }\end{array}$} & High School & 110 & 58,06 & 14,50 & \multirow{3}{*}{1,96} & \multirow{3}{*}{, 143} & \\
\hline & Bachelor's degree & 240 & 56,89 & 14,67 & & & \\
\hline & Master's degree & 32 & 52,31 & 12,90 & & & \\
\hline \multirow{3}{*}{$\begin{array}{l}\text { Turnover Intention } \\
\text { Scale }\end{array}$} & High School & 110 & 7,89 & 3,21 & \multirow{3}{*}{, 06} & \multirow{3}{*}{, 942} & \\
\hline & Bachelor's degree & 240 & 7,83 & 3,13 & & & \\
\hline & Master's degree & 32 & 8,03 & 3,25 & & & \\
\hline
\end{tabular}

$* p<.05$ Categories: High School $=1$; Graduate $=2$; Postgraduate $=3$

In Table 3, it is examined whether there is a significant difference between organizational justice levels and between turnover intentions of trainers according to their educational status. According to $F(2-379)=3,43, p=, 033<, 05$, it is seen that there is a significant difference between the justice levels of trainers related to sub factor of "Distribution Justice" of organizational justice scale in terms of the education levels. This significant difference is due to the higher level of distribution justice sub-dimension of trainers, who are high school graduate and post-graduate, compared to that of those with master's degree. It is seen that the level of distribution of trainers decreases as the level of education increases. According to $\mathrm{p}<.05$, it is seen that there is no significant difference between the levels of justice of trainers according to the educational status regarding the general and procedural and interactional sub-factors of the organizational justice scale. According to $\mathrm{p}<.05$, it is seen that there is no significant difference between turnover intentions of trainers regarding the overall turnover intention scale in terms of their educational status. Although there is no significant difference, it is seen that trainers with master's degree have a slightly higher turnover intention. 
3.3 Third Sub- Problem Is There a Significant Difference between the Organizational Justice Levels and between Their Turnover Intentions According to the Coaching Categories of the Trainers?

Table 4. One-Way ANOVA Results regarding the Significant Differences between the Organizational Justice Levels of the Trainers and between Their Turnover Intentions according to their coaching categories

\begin{tabular}{|c|c|c|c|c|c|c|c|}
\hline & Category & $\mathrm{N}$ & $\overline{\mathrm{X}}$ & $S$ & $\mathrm{~F}(2-379)$ & $\mathrm{p}$ & $\begin{array}{l}\text { Post Hoc } \\
\text { (Tukey) }\end{array}$ \\
\hline \multirow{3}{*}{ Distribution Justice } & Star & 155 & 13,08 & 3,80 & & & \\
\hline & Young & 129 & 12,66 & 4,38 & 2,71 &, 068 & \\
\hline & Big & 98 & 11,80 & 4,82 & & & \\
\hline \multirow{3}{*}{ Procedural Justice } & Star & 155 & 23,95 & 5,93 & & & \\
\hline & Young & 129 & 23,11 & 6,68 & 1,95 &, 142 & \\
\hline & Big & 98 & 22,29 & 7,46 & & & \\
\hline \multirow{3}{*}{ Interactional Justice } & Star & 155 & 21,20 & 4,88 & & & \\
\hline & Young & 129 & 21,02 & 5,64 &, 29 &, 746 & \\
\hline & Big & 98 & 20,65 & 6,32 & & & \\
\hline \multirow{3}{*}{$\begin{array}{l}\text { Organizational Justice } \\
\text { Scale }\end{array}$} & Star & 155 & 58,23 & 12,90 & & & \\
\hline & Young & 129 & 56,78 & 14,47 & 1,75 &, 175 & \\
\hline & Big & 98 & 54,73 & 16,72 & & & \\
\hline \multirow{3}{*}{ Turnover Intention Scale } & Star & 155 & 7,96 & 2,93 & & & \\
\hline & Young & 129 & 7,81 & 3,21 &, 12 &, 889 & \\
\hline & Big & 98 & 7,80 & 3,46 & & & \\
\hline
\end{tabular}

In Table-3, it is examined whether there is a significant difference between organizational justice levels and between turnover intentions of trainers according to coaching categories of the trainers. It is seen that according to the coaching categories, there is no significant difference between the levels of justice of the trainers according to $p<.05$ in the overall and sub-factors of the organizational justice scale. Although there is no significant difference, it is seen that the level of organizational justice of trainers who run the star teams is slightly higher than the level of organizational justice of the trainers who run the young team and big team.

According to $\mathrm{p}<.05$, it is seen that there is no significant difference between turnover intentions of trainers regarding the general of the turnover intention scale in terms of the coaching categories. Although there is no significant difference, it is seen that the turnover intentions of the trainers who run the star team are a little higher. 
3.4 Fourth Sub Problem: Is There a Significant Difference between the Organizational Justice Levels and between Their Turnover Intentions According to the Branches of the Trainers?

Table 5. One-Way ANOVA Results regarding the Significant Differences between the Organizational Justice Levels of the Trainers and between Their Turnover Intentions according to their branches

\begin{tabular}{|c|c|c|c|c|c|c|c|}
\hline & Branch & $\mathrm{N}$ & $\bar{X}$ & $S$ & $\mathrm{~F}(3-378)$ & $\mathrm{p}$ & $\begin{array}{l}\text { Post Hoc } \\
\text { (Tukey) }\end{array}$ \\
\hline \multirow{4}{*}{$\begin{array}{l}\text { Distribution } \\
\text { Justice }\end{array}$} & Team Sports & 184 & 12,95 & 4,14 & \multirow{4}{*}{4,03} & \multirow{4}{*}{, $008^{*}$} & \multirow{4}{*}{$1>3,4>3$} \\
\hline & Individual Sports & 72 & 12,14 & 4,22 & & & \\
\hline & Combat Sports & 54 & 11,02 & 4,70 & & & \\
\hline & Other (Dance \& Folk Dance) & 72 & 13,39 & 4,17 & & & \\
\hline \multirow{4}{*}{$\begin{array}{l}\text { Procedural } \\
\text { Justice }\end{array}$} & Team Sports & 184 & 23,62 & 6,61 & \multirow{4}{*}{5,77} & \multirow{4}{*}{, $001^{*}$} & \multirow{4}{*}{$1>3,4>3$} \\
\hline & Individual Sports & 72 & 23,00 & 6,55 & & & \\
\hline & Combat Sports & 54 & 20,15 & 7,26 & & & \\
\hline & Other (Dance \& Folk Dance) & 72 & 24,83 & 5,44 & & & \\
\hline \multirow{4}{*}{$\begin{array}{l}\text { Interactional } \\
\text { Justice }\end{array}$} & Team Sports & 184 & 21,35 & 5,46 & \multirow{4}{*}{6,48} & \multirow{4}{*}{, $000^{*}$} & \multirow{4}{*}{$1>3,4>3$} \\
\hline & Individual Sports & 72 & 20,38 & 5,19 & & & \\
\hline & Combat Sports & 54 & 18,50 & 5,72 & & & \\
\hline & Other (Dance \& Folk Dance) & 72 & 22,58 & 5,26 & & & \\
\hline \multirow{4}{*}{$\begin{array}{l}\text { Organizational } \\
\text { Justice Scale }\end{array}$} & Team Sports & 184 & 57,92 & 14,11 & \multirow{4}{*}{7,05} & \multirow{4}{*}{, $000 *$} & \multirow{4}{*}{$1>3,4>3$} \\
\hline & Individual Sports & 72 & 55,51 & 14,39 & & & \\
\hline & Combat Sports & 54 & 49,67 & 15,79 & & & \\
\hline & Other (Dance \& Folk Dance) & 72 & 60,81 & 12,85 & & & \\
\hline \multirow{4}{*}{$\begin{array}{l}\text { Turnover } \\
\text { Intention } \\
\text { Scale }\end{array}$} & Team Sports & 184 & 7,85 & 2,94 & \multirow{4}{*}{2,58} & \multirow{4}{*}{, 054} & \\
\hline & Individual Sports & 72 & 8,28 & 3,34 & & & \\
\hline & Combat Sports & 54 & 8,44 & 3,48 & & & \\
\hline & Other (Dance \& Folk Dance) & 72 & 7,07 & 3,15 & & & \\
\hline
\end{tabular}

*p<.05 Categories: Team $=1$; Individual $=2$; Combat $=3$; Other $=4$

In Table-5, it is examined whether there is a significant difference between the organizational justice levels and between the turnover intentions according to trainers' branches. It is seen that in terms of the branches of trainers, there is a significant difference between their levels of justice according to $\mathrm{F}(3-378)=4,03, \mathrm{p}=, 008<, 05$ regarding the sub-factor of "Distribution Justice" of the organizational justice scale. It is seen that in terms of the branches of trainers, there is a significant difference between their levels of justice according to $F(3-378)=5,77, p=, 001<, 05$ regarding the sub-factor of "Procedural Justice" of the organizational justice scale. It is seen that in terms of the branches of trainers, there is a significant difference between their levels of justice according to $F(3-378)=6,48$, $\mathrm{p}=, 000<, 05$ regarding the sub-factor of "Interactional Justice" of the organizational justice scale. It is seen that in terms of the branches of trainers, there is a significant difference between their levels of justice according to $\mathrm{F}(3-378)=7,05, \mathrm{p}=, 000<, 05$ regarding the overall organizational justice scale. These significant differences are due to the fact that levels of trainers with team sports and other sports (dance and folk dances) branches regarding the sub-dimensions of distribution justice, procedural justice, interactional justice and organizational justice scale are higher than the trainers with the combat sports branch. According to $\mathrm{F}(3-378)=2,58, \mathrm{p}=, 054>, 05$, it is seen that there is no significant difference between the turnover intentions according to the branches of the trainers regarding the general of turnover intention scale. Although there is no significant difference, it is seen that the turnover intentions of trainers with branch of combat sports are a little higher.

\section{Discussion}

In this study, it is aimed to determine the relationship between the trainers' organizational justice perceptions and their turnover intentions, and examine educational status, coaching category, branch variables, and support the 
related literature.

When the results of the correlation between the data obtained from the trainers' organizational justice scale and from the turnover intention scale are examined, it is seen that there is a low negatively significant relationship between the justice levels of the sub-dimension of "Distribution Justice" of organizational justice scale and their turnover intentions. it is seen that there is a negatively significant relationship between the justice levels of the sub-dimensions of "Procedural Justice" and "Interactional Justice" of organizational justice scale and their turnover intentions between low and medium level. In a study conducted by Parè and Tremblay (2007), it is stated that there is a negative relationship between the perceptions of procedure justice and employees' turnover intentions. Another contribution of procedural justice to organizations can be expressed as an instrument of increasing interest in inter-organizational groups. That is to say, high sense of procedural justice gives the message that group members are valued (Niehoff and Moormon, 1993). In the study conducted by Bayarçelik and Fındıklı (2017) on organizational justice and turnover intentions of the employees working in private and public banks, it was observed that the employees' turnover intentions decreased in case of the positive perception of distributional and interactional justice.

It is seen that there is a negative relationship between the general organizational justice levels of the trainers and their turnover intentions at a level close to medium level. In short, when the organizational justice levels of the trainers decrease, their turnover intentions increase. Organizational justice is, in the most general sense, a field of psychological research that focuses on the understanding of justice in the workplace (Fortin, 2008). It can be stated that each of the individual and the organizational outputs of the effects of organizational justice level perceived by the employees, namely the justice in the workplace, on the individual and organization depending on the relationships within the organization contributes to the efficiency and performance of the organization by reducing the turnover intention in case of fair distribution of awards and punishment. It can be stated that it is difficult for the employee in this situation to leave the organization or exhibit negative behaviors for his/her organization.

Employees with reduced perceptions of justice also lose their commitment to their organizations, and accordingly they have turnover intentions. For this reason, organizational justice is of utmost importance for organizations. It is necessary to know the behaviors of the employees in case of injustice. The employee's being passive, avoiding the responsibility given, showing negative behaviors, declining business performance, increase in absenteeism, social, mental, physical discomfort and requesting for leaving the job or the conduct of this behavior is the result of the perception of injustice against the organization. One of the consequences of employee's imperception of justice in the organization is the emergence of inefficient studies and poor quality outputs (Karademir and Çoban 2010; Tingül, 2018).

Kiratli (2015) examined the relationship between turnover intention and organizational justice in his thesis study on SME employees, and it was found in this study that the perception of organizational justice had a negative impact on turnover intention and there was a direct relationship between them.

In the related literature, when the studies covering different population groups are examined, it is seen that there are significant negative relationships between organizational justice levels and turnover intentions (Gürpınar, 2006; Özer and Günlük, 2010; Turunç, 2011; Choi, 2011; Çağ, 2011; Örücü and Özafşarlığlu, 2013; Rai, 2013; Karavardar, 2015; Güner, 2016, Sanı and Yavuz, 2018) similar to the results of the current research. Besides, the related studies point out that organisational commitment which is a organisational behavior type is positively correlated primarily with job satisfaction and productivity and it is observed that organisational commitment has significant effects on one's quitting the job (Koç, 2018).

Regarding the education status of the trainers included in the study, it is seen that the organizational justice scale has a significant difference only in the distribution justice sub-dimension. This significant difference is due to the lower level of distribution justice sub-dimension of trainers with master's degree compared to that of those who are high school graduate and post-graduate. In other words, it is seen that the level of distribution justice decreases as the education level of trainers increases. This may be due to the fact that trainers with master's degree think that they should differentiate from the trainers, who are high school graduates and post-graduates, by considering the distribution justice judiciary within the organization due to their further educational levels. As a matter of fact, the employees compare their own gains and the gains that others have achieved. The employee will look at the gain to be correct, moral or ethical when they give the justice distribution judgment. As a result, they can perceive their achievements as fair or unjust. What is important in distribution justice is that employees think that they have a fair share of distributed resources (Cohen and Spector, 2001; Çăg, 2011).

There were no differences between the perceptions of organizational justice and turnover intensions of participants and the category variable they coached. In other words, the organizational justice perceptions and turnover intentions 
of the trainers working in star, young and big categories were similar. Although there was no significant difference, organizational justice perceptions and turnover intention levels of the trainers working in the star category were higher.

Regarding the branch variable of the trainers, it was determined that there was a significant difference in the overall and sub-dimensions of the organizational justice scale, but it was found that there was no significant difference in their turnover intentions. The significant difference was due to the fact that the level of organizational justice perception of trainers engaging in team sports and other sports (dance and folk dances) branches was determined to be higher than the trainers engaging in combat sports. It can be said that the reason of the low level of justice of the trainers engaging in the combat sports is due to the fact that the training, camp, competition periods of the boxing, taekwondo, wrestling, judo etc. sports are difficult branches with heavy conditions and therefore the trainers think that they cannot recompense for their work. The employee's inability to receive the wages that s/he thinks s/he deserves because of his/her contributions to the organization will cause the employees to feel stressful by creating anger (Berkowitz et al., 1987; Tingül, 2018).

As a result, it was determined that as the level of education of the trainers increased, the level of distribution justice levels, one of the sub-dimensions of organizational justice, decreased and the organizational perception levels of the trainers having the branches of combat sports, were found to be low. In addition, as the level of organizational justice of the trainers decreased, their turnover intentions significantly increased. Studies show that individuals are concerned with the issue of justice when they feel that they are or will be exposed to injustice. According to Greenberg (2002), individuals start concerning about the justice when they think that they cannot receive a recompense for their work, when the organizations change, when internal resources are limited and when organizational hierarchy is evident and they feel the power differences (Poussard, 2008; Berber, 2010). It can be stated that, as a result of the high level of their perceptions of justice in the organization where employees work, their productivity, performance and intention to stay increase at the same rate.

\section{References}

Agin, Ö. (2010). Effects of work engagement level on intention to leave the job. Master's Thesis, Kocaeli University, Institute of Social Sciences, Kocaeli.

Akbulut, A., \& Altınkök, M. (2018). The examination of burnout levels of boxing trainers. Journal of Sport, Education and Recreation, 1(1), 31-41.

Arı, A. (2015). Relationship between organizational justice perceptions and organizational commitment levels of school of physical education and sports academicians. Master's Thesis, Selçuk University, Institute of Health Sciences, Konya.

Bannister, B. D., \& Grifeth, R. W. (1986). Applying a causal analytic framework to the Mobley, Horner, and Hollingsworth (1978) turnover model. A useful reexamination. Journal of Management, 12(3), 433-443. https://doi.org/10.1177/014920638601200312

Bayarcelik, E. B., \& Findikli, M. (2017). Mediating role of job satisfaction in the relationship between organizational justice on intention to leave. Beykent University Journal of Social Sciences, 10(1), 16-31.

Berber, A. (2010). An implementation intended to the relationship between employee's organizational justice perceptions and organizational citizenship behaviors. Master's Thesis, Y1ldı Teknik University, Institute of Social Sciences, İstanbul.

Berkowitz, L., Cochran, S., Fraser, C., \& Treasure F. (1987). Pay, equity, job gratifications and comparisons in pay satisfaction. Journal of Applied Psychology, 72(4), 544-551. https://doi.org/10.1037/0021-9010.72.4.544

Byrne, Z. S. (2005). Fairness reduce the negative effects of organizational politics on turnover intentions, citizenship behavior and job performance. Journal of Business and Psychology, 20(2), 175-200. https://doi.org/10.1007/s10869-005-8258-0

Can, A. (2014). Quantitative data analysis in scientific research process with SPSS 2.end. Ankara: Pegem.

Chang, C., \& Dubinsky, A. J. (2005). Organizational justice in sales force: A literature review with propositions. Journal of Business to Business Marketing, 12(1), 35-71. https://doi.org/10.1300/J033v12n01_03

Choi, S., (2011). Organizational justice and employee work attitude: The federal case. The American Review of Public Administration, 41(2), 185-204. https://doi.org/10.1177/0275074010373275

Cohen-Charash, Y., \& Spector, P. (2001). The role of justice in organizations: A meta-analysis. Organizational 
Behavior and Human Decision Process, 86(2), 278-321. https://doi.org/10.1006/obhd.2001.2958

Colquitt, J. A. (2001). On The dimensionality of organizational justice: A construct validation of a measure. Journal Of Applied Psychology, 86, 386-400. https://doi.org/10.1037/0021-9010.86.3.386

Çağ, A. (2011). A research about determining the effect of perceived organizational justice to the intention of the organizational cynicism and leaving from work. Master's Thesis, Afyon Kocatepe University, Institute of Social Sciences, Afyon.

Demir, N. (2007). Organizational culture and job satisfaction. İstanbul: Türkmen Publisher.

Eğilmezkol, G. (2011). Organizational justice and organizational commitment in work life, a study aimed at the analysis of the organizational justice and organizational commitment of the employees in a public bank. Master's Thesis, Gazi University, Institute of Social Sciences, Ankara.

Eren, A. (2007). An econometric analyzes about voluntary turnover. Doctoral Dissertation, Gazi University, Institute of Social Sciences, Ankara.

Erkuş, A. (2013). Scientific research process for behavioral sciences. Ankara: Seçkin.

Fischer, R. (2004). Rewarding employee loyalty: An organizational justice approach. International Journal of Organizational Behavior, 8(3), 486-503.

Fortin, M. (2008). Perspectives on organizational justice: Concept clarification, social context integration, time and links with morality. International Journal of Management Reviews, 10(2), 93-126. https://doi.org/10.1111/j.1468-2370.2008.00231.x

Greenberg, J. (1990). Organizational justice: Yesterday, today and tomorrow. Journal of Management, 16(2), 399-432. https://doi.org/10.1177/014920639001600208

Greenberg, J. (2002). Who stole the money, and when? Individual and situational determinants of Employee theft. Organizational Behavior and Human Decision Processes, 89, 985-1003. https://doi.org/10.1016/S0749-5978(02)00039-0

Güner, B. (2016). The effect of organizational justice on turnover intention and the mediating role of emotional exhaustion: A study on educational institutions. Master's Thesis, Orta Doğu Teknik University, Institute of Social Sciences, Ankara.

Gürpınar, G. (2006). An emprical study of relationships among organizational justice, organizational commitment, leader-member exchange and turnover intention. Master's Thesis, Yeditepe University, Institute of Social Sciences, İstanbul.

İçerli, L. (2010). Organizational justice: A theorical approach. Journal of Entrepreneurship and Development, 5(1), 67-92.

İyigün, N. Ö. (2012). Organizational justice: A theoritical approach. İstanbul Ticaret University Journal of Social Sciences, 11(21), 49-64.

Karademir, T., \& Çoban, B. (2010). View of the organizational justice theory in sport management constitution. Nigde University Journal of Physical Education and Sport Sciences, 4(1), 48-62.

Karasar, N. (2009). Scientific research method. Ankara: Nobel Publisher.

Karavardar, G. (2015). The impact of organizational justice on job satisfaction, Organizational commitment and turnover intention. Int. Journal of Management Economics and Business, 11(26), 139-150. https://doi.org/10.17130/ijmeb.2015.11.26.688

Kiratl1, M. (2015). Intermediary role of organizational trust within the effect of organizational justice on intention for quitting job: An application on manufactured home furniture company. Master's Thesis, Türk Hava Kurumu University, Institute of Social Sciences, Ankara.

Kıray, A. (2011). An empirical study towards identifying the relationship between organizational justice and organizational commitment. Master's Thesis, Çanakkale Onsekiz Mart University, Institute of Social Sciences, Çanakkale.

Kim, S. (2009). The impact of met-expectation of organizational justice on attitudinal and behavioral outcomes of intercollegiate athletics coaches. Doctor of Philosophy Degree, The University of Tennessee, Knoxville.

Koç, M. (2018). Research on correlations between academicians' levels of organizational commitment and their 
intention to quit their job: A comparison of state and foundation universitie. Journal of Education and Learning, 7(1), 163-173. https://doi.org/10.5539/jel.v7n1p163

Köklü, N., Büyüköztürk, Ş. \& Bökeoğlu, Ç. Ö. (2007). Statistics for social sciences. Ankara: Pegem.

Kuşci, E. (2014). Perceptions of organizational justice academics in universities (Yüzüncü Yıl University example), Master's Thesis, Yüzüncü Yıl University Institute of Educational Sciences, Van.

Lipponen, J., Olkkonen, M. E., \& Myyry, L. (2004). Personal value orientation as a moderator in the relationships between perceived organizational justice and its hypothesized consequences. Social Justice Research, 17(3), 275-292. https://doi.org/10.1023/B:SORE.0000041294.68845.0f

Luo, Y. (2007). The independent and interactive roles of procedural, distributive and interactional justice in s trategic alliances. Academy of Management Journal, 50, 644-664. https://doi.org/10.5465/amj.2007.25526452

Masterson, S. S., Lewis, K., Goldman, B. M. \& Taylor, M. S. (2000). Integrating justice and social exchange: The differing effects of fair procedures and treatment on work relationships. The Academy of Management Journal, 43(4), 738-748.

Miller, P. E. (2007). The relationship between job satisfaction and intention to leave: A study of hospice nurses in a for-profit Corporation. Ph.D., Capella University, Ann Arbor. ProQuest, UMI Dissertations Publisekencihing.

Mobley, W. H., Horner, S. O., \& Hollingsworth, A. T. (1978). An evaluation of precursors of hospital employee turnover. Journal of Applied Psychology, 63(4), 408-414. https://doi.org/10.1037/0021-9010.63.4.408

Morgan, G. A., Leech, N. L., Gloeckner, G. W., \& Barrett, K. C. (2004). SPSS for introductory statistics: Use and interpretation. Psychology Press. https://doi.org/10.4324/9781410610539

Niehoff, B. P., \& Moormon, R. H. (1993). Justice as a mediator of the relationship between methods of monitoring and organizational citizenship behavior. Academy of Management Journal, 36(3), 527-556.

Örücü, E., \& Özafşarlıoğlu, S. (2013). The influence of organizational justice on the turnover intention: A study in The Republic of South Africa. Mustafa Kemal University Journal of Social Sciences Institute, 10(23), 335-358.

Özer, G., \& Günlük, M. (2010). The effect of organizational justice on accountants' job satisfaction and turnover intention. Gaziantep University Journal of Social Sciences, 9(2), 459-481.

Parè, G., \& Tremblay, M. (2007). The Influence of high-involvement human resourcesp practice, organizational commitment, and citizenship behaviors on information technology professionals turnover intentions. Group and Organization Management, 32(3), 326-357. https://doi.org/10.1177/1059601106286875

Ployhart, R. E. \& Ryan, A. M. (1997). Toward an Explanation of Applicant Reactions: An Examination of Organizational Justice and Attribution Frameworks. Organizational Behavlor and Human Decision Processes, 72(3), 308-335. https://doi.org/10.1006/obhd.1997.2742

Poussard, M. J. (2008). How does communication and culture affect the sense of justice? Management, Communication, Culture. 1.edn. İstanbul: Arıkan Publish.

Rai, G. S. (2013). Impact of organizational justice on satisfaction, commitment and turnover intention: Can fair treatment by organizations make a difference in their workers' attitudes and behaviors? International Journal of Human Sciences, 10(2), 260-284.

San1, R. A., \& Yavuz, E. (2018). Effects of organizational justice perceptions of employees on the intention to leave. Journal of Tourism and Gastronomy Studies, 6(4), 754-778. https://doi.org/10.21325/jotags.2018.333

Sayın, A., \& Şahin, M. Y. (2017). Adaptation of organizational justice in sport scale into Turkish language: Validity and reliability study. Journal of Education and Training Studies, 5(2), 207-214. https://doi.org/10.11114/jets.v5i2.2071

Söyük, S. (2007). Search about the influence of the organizational justice on job satisfaction and about the nurses working in the private hospitals in Istanbul. Doctoral Dissertation, İstanbul University Journal of Social Sciences Institute, İstanbul.

Tingül, S. D. (2018). The effect of organizational justice perception on employees' leaving behaviours. Master's Thesis, Bahçeşehir University, Institute of Social Sciences. İstanbul.

Turunç, Ö. (2011). The effect of Organizational justice and organizational identification on employee's turnover intention: The mediating effect of organizational identification. ISGUC The Journal of Industrial Relations and 
Human Resources, 13(1), 143-166. https://doi.org/10.4026/1303-2860.2011.0168.x

Vigoda, E. (2000). Organizational politics, job attitudes, and work outcomes: Exploration and implications for the public sector. Journal of Vocational Behavior, 57, 326-347. https://doi.org/10.1006/jvbe.1999.1742

Weisberg, J., \& Kirsschenbaum, A. (1991). Employee turnover intentions: Implications from a national sample. The International Journal of Human Resource Management, 2(3), 359-375. https://doi.org/10.1080/09585199100000073

Y1ldiz, S. M. (2013). The effect of quality of work life on employee turnover intention in sports and physical activity organizations. Ege Academic Review, 13(3), 317-324.

Y1lmaz, B., \& Halıc1, A. (2010). The factors affecting turnover: A research study in secretarial staff. International Journal of Economic and Administrative Studies, 2(4), 94-108.

Y1lmaz, G. (2004). The effect of organizational justice perception regarding human resource practices on employees attitudes and behaviors. Doctoral Dissertation, İstanbul University Journal of Social Sciences Institute, İstanbul. 